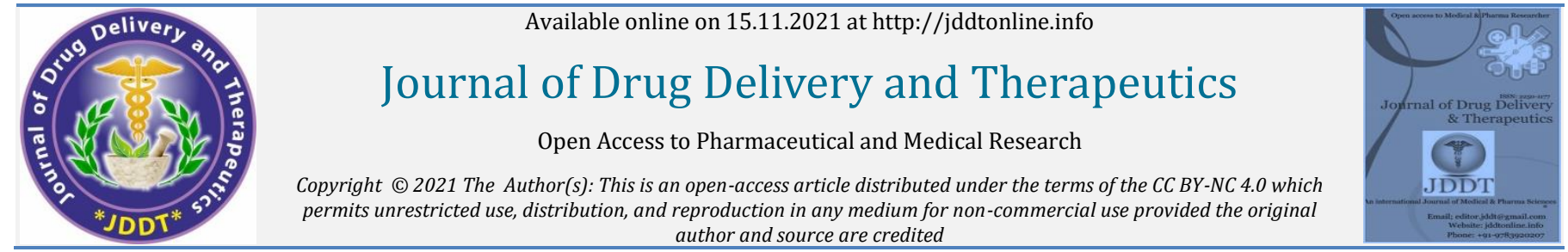
author and source are credited

${ }_{\text {open }}$ Access Full Text Article $\quad$ (c) $)$ (1) $(9)$

\title{
GC-MS, FTIR and Antiulcer Screening of Aqueous Seed Extract and Oil of Nigella sativa in Wistar Rats
}

\author{
Bruce, S.0. ${ }^{1}$, Nwafor, O.I. ${ }^{1}$ Omoirri, M.A. ${ }^{2}$, Adione, N.M. ${ }^{3}$, Onyeka, I.P. ${ }^{1}$, Ezeoru, V.C ${ }^{4}$ \\ ${ }^{1}$ Department of Pharmacognosy and Traditional Medicine, Faculty of Pharmaceutical Sciences, Nnamdi Azikiwe University, Awka, Anambra State, \\ Nigeria. \\ ${ }^{2}$ Department of Pharmacology and Toxicology, Faculty of Pharmaceutical Sciences. Federal University of Oye-Ekiti, Ekiti state. \\ ${ }^{3}$ Department Pharmaceutical and Medicinal Chemistry, Faculty of Pharmaceutical Sciences, Nnamdi Azikiwe University, Awka, Anambra State, Nigeria. \\ ${ }^{4}$ Department of Laboratory Science, Nnamdi Azikiwe University, Awka, Anambra State, Nigeria.
}

\section{Article Info:}

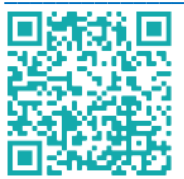

\section{Article History:}

Received 13 September 2021

Reviewed 18 October 2021

Accepted 25 October 2021

Published 15 November 2021

\section{Cite this article as:}

Bruce SO, Nwafor OI. Omoirri MA, Adione NM, Onyeka IP, Ezeoru VC, GC-MS, FTIR and Antiulcer Screening of Aqueous Seed Extract and Oil of Nigella sativa in Wistar Rats, Journal of Drug Delivery and Therapeutics. 2021; 11(6):48-60

DOI: http://dx.doi.org/10.22270/jddt.v11i6.5036

\section{*Address for Correspondence:}

Bruce, Stella Omokhefe, Department of Pharmacognosy and Traditional Medicine, Faculty of Pharmaceutical Sciences, Nnamdi Azikiwe University, Awka, Anambra State, Nigeria.

\section{Abstract}

Peptic ulcer disease (PUD) is a sore in the lining of the stomach or duodenal mucosa. This study was aimed at evaluating the antiulcer activity of the aqueous extract of Nigella sativa (black seed) and its constitutents. The pharmacognostic properties of the dry seeds were determined. The seeds were extracted using two methods digestion and hydro-distillation. The acute toxicity, phytochemical constituents and the antiulcer evaluation were performed on ethanolinduced ulcer in wistar rats using a standard method. FTIR and GC-MS analysis of the aqueous seed extract was also determined using standard methods. Nigella sativa seed shows the presence of starch grains, lignified tissues, tannins, cellulose, protein and oil globules. The aqueous extract has a high safety margin. The phytochemical studies revealed the presence of saponins, flavonoids, alkaloids, tannins, glycosides, fats and oil. The black seed aqueous and oil extract at $500 \mathrm{mg} / \mathrm{kg}$ significantly reduced the acidity, total acidity, and ulcer index, and $\mathrm{pH}$ of gastric content when compared with the positive control (Famotidine). The FTIR analysis identified the presence of the following functional groups chloro, ether, amine, carboxylic acid, nitriles, methylene, alcohol, while the GC-MS identified five compounds such as glycerin, nHexadecanoic acid, 9, 12-octadecadienoic acid-methyl ester, 9, 12-octadecadienoic acid and 9, 12-octadecadienoyl chloride. The pharmacognostic properties can act as a reliable tool for the standardization of the plant part. This study suggests that aqueous and oil extract possess antiulcer properties. Thus the aqueous and oil extract of black seed can be considered as antiulcer medication traditionally.

Keywords: Nigella sativa, Black seed, Pharmacognostic, Phytochemical, Acute toxicity (LD $\left.{ }_{50}\right)$, Antiulcer.

\section{INTRODUCTION}

Nigella sativa L, known as black cumin or black seed (family, Ranunculaceae) is used as a spice in Indian and Middle Eastern cuisine. In Asia, Middle East, and Africa, it is used as an herb and oil. Gastrointestinal tract (GIT) is responsible for the absorption of nutrients, digestion of food, and excretion of unabsorbed waste products ${ }^{1}$. It is the organ that provides a continuous supply of water, electrolyte, and nutrients to the whole part of the body. Peptic ulcer disease or PUD is a pathological condition of this organ and refers to the painful spot characterized by the presence of an ulcer in any part of GIT which is exposed to acid and pepsin. Nigella sativa L ethnomedicinal properties include antimicrobial, antidiabetic, antifertility, antioxytocic, analgesic, anthelmintic, antihypertensive, antiulcer, circulatory and immune system support ${ }^{2}$. A Gastro duodenal lesion due to hyperacidity leads to peptic ulcerations which are erosions of the mucosal epithelial lining of the gastrointestinal tract ${ }^{3}$. Despite the pathophysiology of peptic ulceration not been completely elucidated, it is known that an imbalance between aggressive factors (acid and pepsin secretion) and cytoprotective factors of the gastric mucus membrane (mucus and bicarbonate secretion) result in gastric ulceration ${ }^{4}$. The most common symptoms of peptic ulcer include epigastric and nocturnal pain which are alleviated by either food intake or antacids; other symptoms include indigestion, nausea, loss of appetite, fatty food intolerance, and heartburn.5,6 The aetiology of gastric ulcer involves environmental factors such as alcoholic beverages and non-steroidal anti-inflammatory drugs (NSAIDs) usage, Helicobacter pylori, genetic factors amongst others ${ }^{7.8}$. The chemical composition of $N$. sativa seeds contains unsaturated fatty acids with terpene alcohols, traces of alkaloids (isochinoline alkaloids and pyrazol alkaloids). In the 
essential oil contains thymoquinone, p-cymene, pinene, dithymoquinone and thymohydroquinone ${ }^{2}$. Peptic ulcer of the stomach and duodenum was known in the 1700s, there is a revolution of understanding and management of PUD after the discovery of Helicobacter pylori. Several treatments are available for peptic ulcers such as antacids, H2 blockers, proton-pump inhibitors, antibiotics, and combination therapy. Adverse effects and decreased efficacy over time have limited the use of some anti-ulcer drugs. Reports on clinical evaluation of conventional anti-ulcerogenic drugs showed that there are incidences of relapses, adverse effects and danger of drug interactions during ulcer therapy 9 . The high cost of newly available drugs for peptic ulcer disease is responsible for the persistence, morbidity and mortality of the disease in third world countries due to low per capita income ${ }^{10}$. As a result, the search for an ideal antiulcer drug continues and has also been extended to herbs for new and novel molecules that afford better protection and reduction in the incidence of relapse ${ }^{10}$. Herbal drugs are used widely even when their biologically active compounds are unknown because of their assumed effectiveness, availability, lesser side-effects and relatively low cost $^{11}$. The study was aimed to evaluate the GC-MS, FTIR and antiulcer screening of aqueous seed extract and oil of Nigella sativa in wistar rats

\section{MATERIALS AND METHODS}

\section{Reagents and materials}

Ethanol, Ehtylacetate, Butanol, n-Hexane (HD England), Famotidine (CP Pharmaceuticals,UK), Glass column, flasks, beakers, test tubes, measuring cylinders, rotary evaporator, Analytical Weighing Balance (Metler H30, Switzerland), Spectrophotometer (B. Bran Scientific \& Instrument Company, England), Water Bath (Techmel \& Techmel, Texas, USA), Appendoff tube, plain bottle, and Micropippete (Finnipipette ${ }$ Labsystems, Finland).

\section{Sample preparation}

The Nigella sativa seeds were collected from Roban stores Awka in September, 2020. Samples were authenticated by a taxonomist in the department of botany Mr Okeke Ebele in Nnamdi Azikiwe University Awka, air-dried in a dark room without sunlight, grinded and then they were stored in a cool room $\left(4{ }^{\circ} \mathrm{C}\right)$ for subsequent experiments.

Methods

\section{Extraction Procedures}

\section{Seed processing}

Digestion method was used in extracting the seed. Digestion is an extraction method that involves the use of moderate heat during extraction process. The solvent of extraction is poured into a clean container followed by powdered drug material. The mixture is placed over water bath or in an oven at a temperature about $50{ }^{\circ} \mathrm{C} 12$.

\section{Oil extraction}

Hydro-distillation method was used in extracting the oil. The air-dried seeds of Nigella sativa were grinded right before the extraction process. In order to protect the plant materials from overheating or charring by direct steam, grinded seeds were immersed in distilled water in a round bottom flask on a heater ${ }^{13}$. Essential oil of the seeds was extracted by hydrodistillation Clevenger apparatus method (Fig. 1) at the boiling range of water and atmospheric pressure. The extraction process was optimized with respect to time, heating power $(250,300,350 \mathrm{~W})$ and solid $(\mathrm{g})$ to solvent $(\mathrm{ml})$ ratio $(1: 3,1: 10$, $1: 12)$.

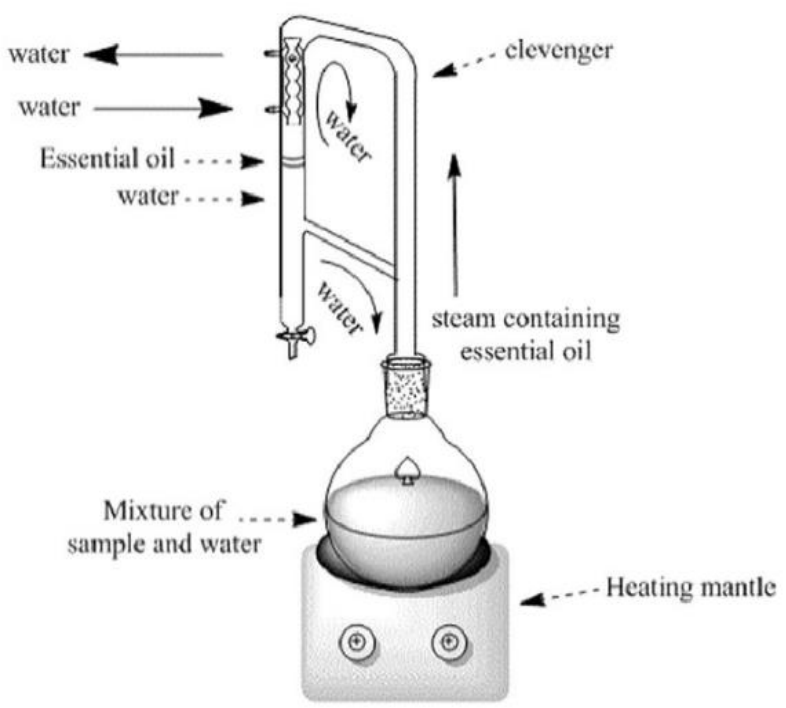

Figure 1: Hydro-distillation Clevenger apparatus system

Extracted essential oil was dried over anhydrous sodium sulfate to remove all the water and then stored it in darksealed-vial at $4{ }^{\circ} \mathrm{C}$ for further tests. The yield of essential oil was calculated by the following equation:

$$
\mathrm{Y}=\frac{\mathrm{V} \times 100}{\mathrm{~W}}
$$

Equation 1

Where $\mathrm{y}$ is the yield of essential oil (\%), $\mathrm{V}$ is the volume of collected essential oil ( $\mathrm{ml})$ and $\mathrm{W}$ is the weight of the plant material $(\mathrm{g})$.

Pharmacognostic studies

\section{Microscopic examination}

Microscopic studies were carried out by preparing thin sections of leaf. The thin sections were further washed with water, staining was done by clearing in chloral hydrate solution then heat fixed and allowed to cool, then mounted using glycerine. The specimen was gently covered with a cover slip and placed on the stage of the microscope for observation $(40 x)^{14}$.

\section{Chemomicroscopic examination}

Examination of the powder for lignin, starch, mucilage, calcium oxalate crystals, cellulose, fatty oil and protein were carried out using standard techniques ${ }^{15}$.

\section{Physicochemical analysis}

The parameters which were studied are moisture content, ash values and extractive values 16,17

\section{Phytochemical analysis}

\section{Qualitative phytochemical analysis}

The plant crude extracts were tested for the presence Reducing sugar, Hydrogen cyanide, Soluble carbohydrate, Tannins, Alkaloids, Steroids, Terpenoids, Phenol, Flavonoids, Saponins and Glycosides using standard methods ${ }^{15}$. 


\section{Acute Toxicity}

The acute toxicity study of Nigella sativa was carried out according to the method employed by Lorke's method ${ }^{18}$ but modified, using a total of 21 rats ${ }^{19,} 20$.

\section{Animal husbandry}

Thirty Wistar Rats (120-150 g) were obtained from the animal house, Department of Pharmacology and Toxicology, Nnamdi Azikiwe University Awka. They were fed with grower mash (vital feed, grand cereal) and water and kept for 2 weeks to acclimatize with the animal house conditions (a crossventilated room with temperature between $25{ }^{\circ} \mathrm{C}$ and $32{ }^{\circ} \mathrm{C}$, $12 \mathrm{~h}$ light/12 $\mathrm{h}$ dark cycle) before the commencement of the study. The research was conducted in accordance with the Nnamdi Azikiwe University Research and Ethical Committee guidelines, the ARRIVE guidelines (reporting of in vivo experiment), and the National Institutes of Health (NIH) guide for the CARE and use of laboratory animals (NIH Publications No. 8023, revised 1978).

\section{Experimental Design:}

The thirty (30) Wistar rats were randomly divided into six groups of five rats each and fasted for $18 \mathrm{~h}$ before administration of extract. Rats in Group 1 were pretreated with $1 \mathrm{ml} / \mathrm{kg}$ Distilled water, the rats in Group 2 were pretreated with $30 \mathrm{mg} / \mathrm{kg}$ Famotidine, while those in Groups 3 and 4 were pretreated with aqueous extract of $N$. sativa at 250 $\mathrm{mg} / \mathrm{kg}$ and $500 \mathrm{mg} / \mathrm{kg}$. Group 5 and 6 were pretreated with Black seed oil at $1 \mathrm{ml}$ and $1.5 \mathrm{ml}, 30$ mins before the administration of $1 \mathrm{ml} 80 \%$ ethanol. All the rats were sacrificed $1 \mathrm{~h}$ after $80 \%$ ethanol administration using ketamine injection, and the stomachs were cut open, the stomach content were deposited in a beaker, the ulcer index was determined. The gastric content was collected in test tube and centrifuged at $3000 \mathrm{rpm}$ for $10 \mathrm{~min}$, Total acidity (m $\mathrm{Eq} / \mathrm{L})$, Gastric acid volume ( $\mathrm{ml}$ ) and $\mathrm{pH}$ of the supernatant was measured using digital $\mathrm{pH}$ meter ${ }^{21,22,23 .}$

\section{Histopathology procedure}

The stomachs were fixed in $10 \%$ neutral buffered formalin, dehydrated in graded series of alcohol, cleared in xylene, and embedded in paraffin wax. The tissues were sectioned at $5 \mu \mathrm{m}$ with a rotary microtome and stained with hematoxylin and eosin ( $\mathrm{H}$ and $\mathrm{E}$ ) and cresyl violet stain ${ }^{24}$.

\section{Fourier Transform Infrared Spectroscopic (FTIR) Analysis}

Buck scientific M530 USA FTIR was used for the analysis. This instrument was equipped with a detector of deuterated triglycine sulphate and beam splitter of potassium bromide. The software of the Gram A1 was used to obtain the spectra and to manipulate them. An approximately of $1.0 \mathrm{~g}$ of samples, $0.5 \mathrm{mi}$ of nujol was added, they were mixed properly and placed on the salt pallet. During measurement, FTIR spectra was obtained at frequency regions of $4,000-600 \mathrm{~cm}^{\wedge} 1$ and coadded at 32 scans and at $4 \mathrm{~cm}^{\wedge} 1$ resolution. FTIR spectra were displayed as transmitter values 25 .

\section{GC/MS Analysis}

The Gas chromatography-mass spectrometry (GC-MS) analyses of $N$. sativa aqueous seed extract was carried out in Agilent Technologies (Wilmington, Delaware, USA) equipment with a column HP-5MS (30 $\mathrm{m} \times 0.25 \mathrm{~mm} 1 \mathrm{D} X 0.25)$. A sample of $1 \mu \mathrm{L}$ of each extract was injected. For detection, an ionization system with energy of $70 \mathrm{eV}$ was used. The flow rate of carrier gas was constant and it was maintained at 1.1 $\mathrm{mL} / \mathrm{min}$. The injection temperature was $250^{\circ} \mathrm{C}$. The warming program of the oven was isothermal for $5 \mathrm{~min}$ at $60{ }^{\circ} \mathrm{C}$ followed by a warming of $5{ }^{\circ} \mathrm{C} / \mathrm{min}$ up to $100{ }^{\circ} \mathrm{C} / \mathrm{min}(2 \mathrm{~min})$, and $10{ }^{\circ} \mathrm{C} / \mathrm{min}$ up to $250^{\circ} \mathrm{C} / \mathrm{min}(5 \mathrm{~min})$. The interpretation of the mass spectra was made using the National Institute of Standard and Technology (NIST) library 26, 27, 28.

\section{Statistical analysis}

Data obtained from the study were analyzed using Statistical Package for Social Sciences (SPSS-21). Results were presented as mean \pm Standard error of mean (SEM) of sample replicates. Raw data were subjected to one way analyses of variance (ANOVA) followed by post hoc turkey's test. $\mathrm{p}<0.05$ were considered to be statistically significant.

\section{RESULTS}

\section{Microscopy}

Table 1: Microscopy

\begin{tabular}{ll}
\hline Parameter & Black seed \\
\hline Starch grains & Present \\
Lignified tissues & Present \\
Calcium oxalates & Absent \\
Cystolith & Absent \\
Tannin & Present \\
Cellulose & Present \\
Gum/Mucilage & Absent \\
Protein & Present \\
Oil globules & Present \\
\hline
\end{tabular}

Table 2: Chemomicroscopic Examination

\begin{tabular}{lll}
\hline TEST REAGENT & OBSERVATION & INFERENCE \\
\hline Sample + phloroglucinol + Conc Hcl & Red colour observed & Lignin Present \\
Sample + iodine & Blue colour observed & Starch Present \\
Sample + Hydrochloric acid & No crystals dissolved & Calcium Oxalate Absent \\
Sample + Ruthenium red & No colour change & Mucillage Absent \\
Sample + clor-zinc iodine or N/50 idoine +66\% H2SO4 & Blue colour observed & Cellulose Present \\
Sample + Sudan IV reagent & Pink colour observed & Fatty acid present \\
Sample + 1\% Picric acid and millions reagent & Red colour observed & Protein Present \\
\hline
\end{tabular}




\section{Nigella sativa}

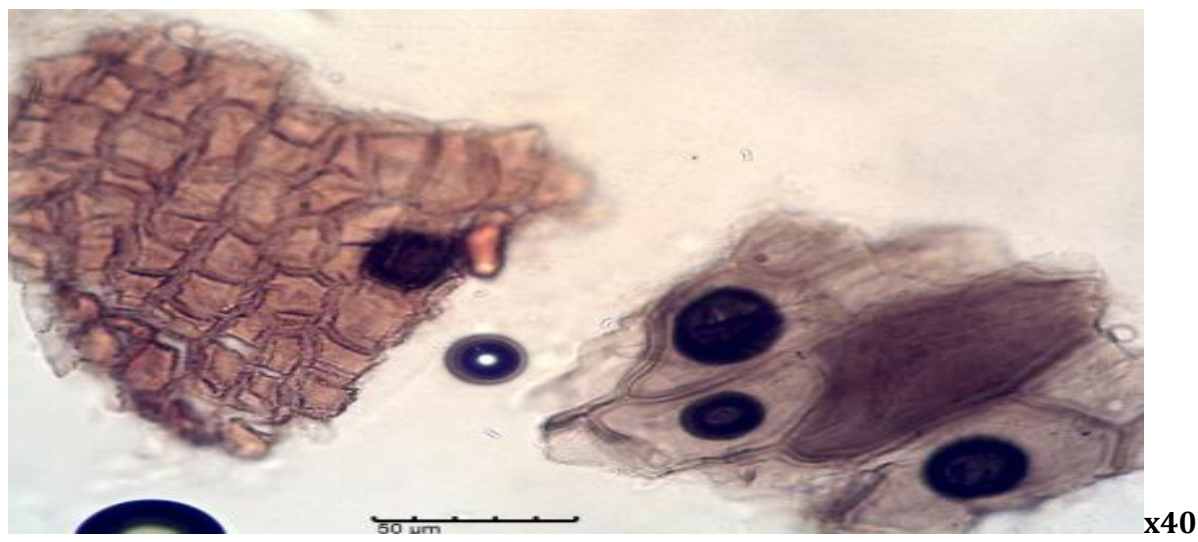

Figure 2: Chemomicrograph of the seed powder showing a pack of parenchymatous cells of the cotyledon (lignified) and fraction of the testa showing epidermal cells

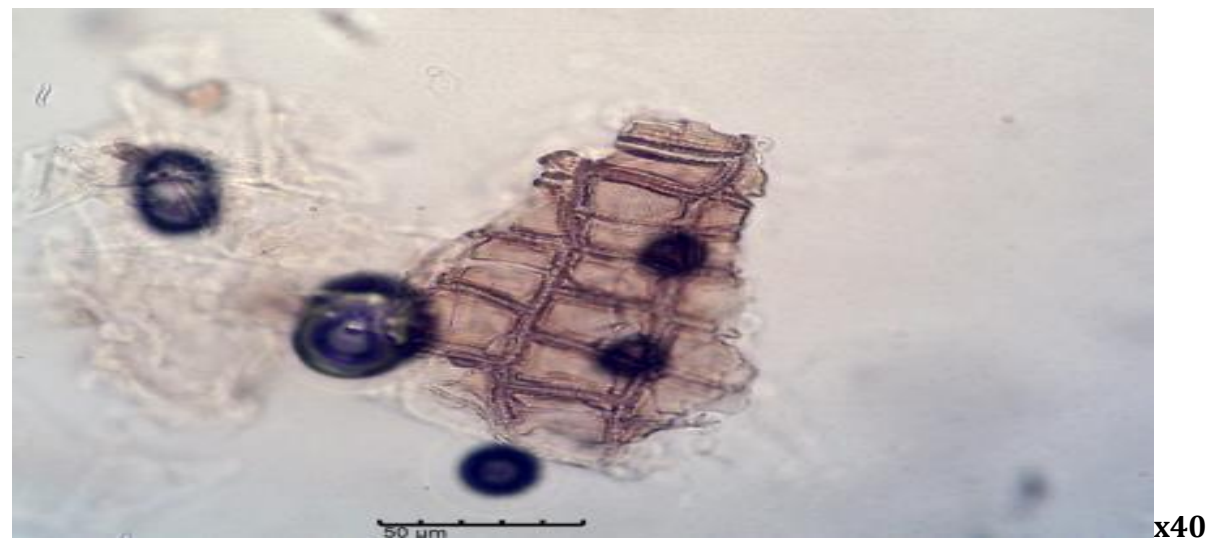

Figure 3: Chemomicrograph of the seed powder showing parenchyma cells of the endosperm

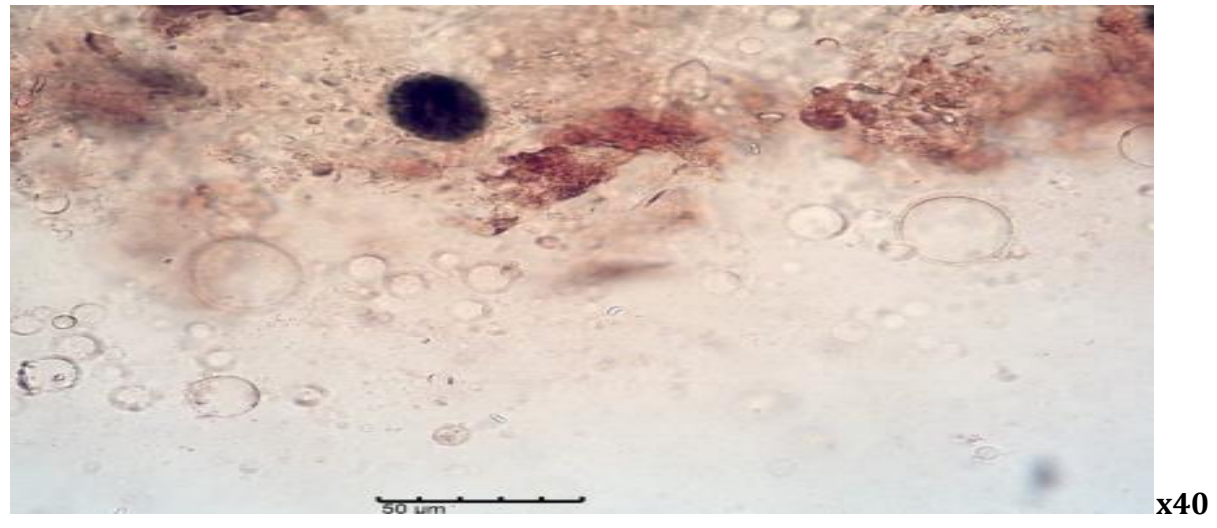

Figure 4: Chemomicrograph of the seed powder showing abundant oil globules/cells and clustered stone cells (lignified) 


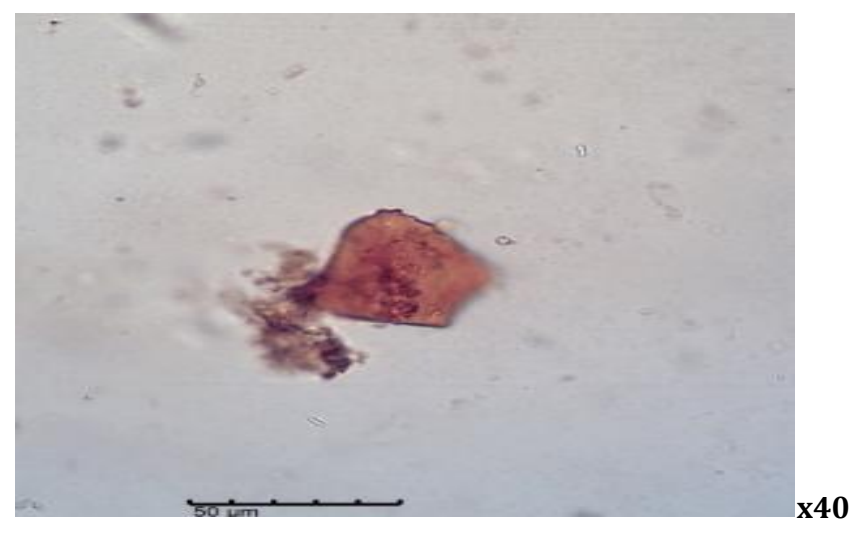

Figure 5: Chemomicrograph of the seed powder showing an isolated lignified stone cell

\section{Proximate analysis}

Table 3: Proximate analysis of Nigella sativa seed

\begin{tabular}{ll}
\hline Parameter & \% Composition \\
\hline Moisture content & 5.3 \\
Total ash & 4.8 \\
Acid - insoluble ash & 1.0 \\
Water - soluble ash & 1.3 \\
Acid insoluble ash & 1.0 \\
Alcohol - soluble extractive & 7.0 \\
Water - soluble extractive & 8.5 \\
\hline
\end{tabular}

Values of \% composition

\section{Phytochemical Analysis}

Table 4: Phytochemical Analysis of Nigella sativa seed

\begin{tabular}{|c|c|c|}
\hline Phytochemicals & & Crude extract \\
\hline Saponins & & ++ \\
\hline Tannins & & + \\
\hline Carbohydrates & & + \\
\hline Reducing Sugars & & + \\
\hline Flavonoids & & +++ \\
\hline Alkaloids & & +++ \\
\hline Glycosides & & + \\
\hline Steroids & & + \\
\hline Fats and oils & & +++ \\
\hline Proteins & & + \\
\hline Acidic compounds & & + \\
\hline \multicolumn{3}{|c|}{$\begin{array}{l}(-)=\text { Not Present, }(+)=\text { Present in small concentration, }(++)=\text { Present } \\
\text { in moderately high concentration, }(+++)=\text { Present in high } \\
\text { concentration. }\end{array}$} \\
\hline \multicolumn{3}{|l|}{ Acute toxicity } \\
\hline \multicolumn{3}{|c|}{ Table 5: Acute toxicity of Nigella sativa seed } \\
\hline PHASES & DOSE (mg/kg) & MORTALITY \\
\hline \multirow[t]{3}{*}{ PHASE 1} & 10 & $0 / 3$ \\
\hline & 100 & $0 / 3$ \\
\hline & 1000 & $0 / 3$ \\
\hline \multirow[t]{4}{*}{ PHASE 2} & 2000 & $0 / 3$ \\
\hline & 3000 & $0 / 3$ \\
\hline & 4000 & $0 / 3$ \\
\hline & 5000 & $0 / 3$ \\
\hline
\end{tabular}

Table 6: Dose dependent studies of Nigella sativa seed extract using ethanol induced ulcer model rat model

\begin{tabular}{|l|l|l|l|l|l|}
\hline Pre-treatment & Post-treatment & Ulcer Index & $\begin{array}{l}\text { Total Acidity } \\
\text { (m Eq/L) }\end{array}$ & $\begin{array}{l}\text { Gastric Acid } \\
\text { Volume (ml) }\end{array}$ & \begin{tabular}{l} 
pH \\
\hline Distilled water $(1 \mathrm{ml} / \mathrm{kg})$
\end{tabular} \\
\hline Famotidine $(30 \mathrm{mg} / \mathrm{kg})$ & $80 \%$ ethanol & $13.00 \pm 0.54^{* *}$ & $120.4 \pm 0.40^{* *}$ & $7.20 \pm 0.09^{* *}$ & $2.2 \pm 0.10^{* *}$ \\
\hline Aqueous extract $(250 \mathrm{mg} / \mathrm{kg})$ & $80 \%$ ethanol & $8.68 \pm 0.54^{*}$ & $89.09 \pm 0.74^{*}$ & $6.07 \pm 0.51^{*}$ & $4.7 \pm 1.0^{*}$ \\
\hline Aqueous extract $(500 \mathrm{mg} / \mathrm{kg})$ & $80 \%$ ethanol & $4.05 \pm 0.9^{*}$ & $55.6 \pm 0.13^{*}$ & $4.45 \pm 0.5^{*}$ & $3.67 \pm 1.76^{*}$ \\
\hline Black seed oil $(1 \mathrm{ml})$ & $80 \%$ ethanol & $8.87 \pm 0.4^{*}$ & $80.9 \pm 0.33^{*}$ & $6.2 \pm 0.45^{*}$ & $3.74 \pm 1.86^{*}$ \\
\hline Black seed oil $(1.5 \mathrm{ml})$ & $80 \%$ ethanol & $4.62 \pm 0.19^{*}$ & $67.1 \pm 0.31^{*}$ & $5.00 \pm 0.71^{*}$ & $3.54 \pm 2.00^{*}$ \\
\hline
\end{tabular}

Values are presented as mean \pm Standard error of mean (SEM), $\mathrm{n}=5$. Statistical comparisons as follows: significant at $\mathrm{p}<0.01^{* *}$ and $\mathrm{p}<0.05^{*} \operatorname{compared~}$ to negative control group. 


\begin{tabular}{|c|c|c|}
\hline 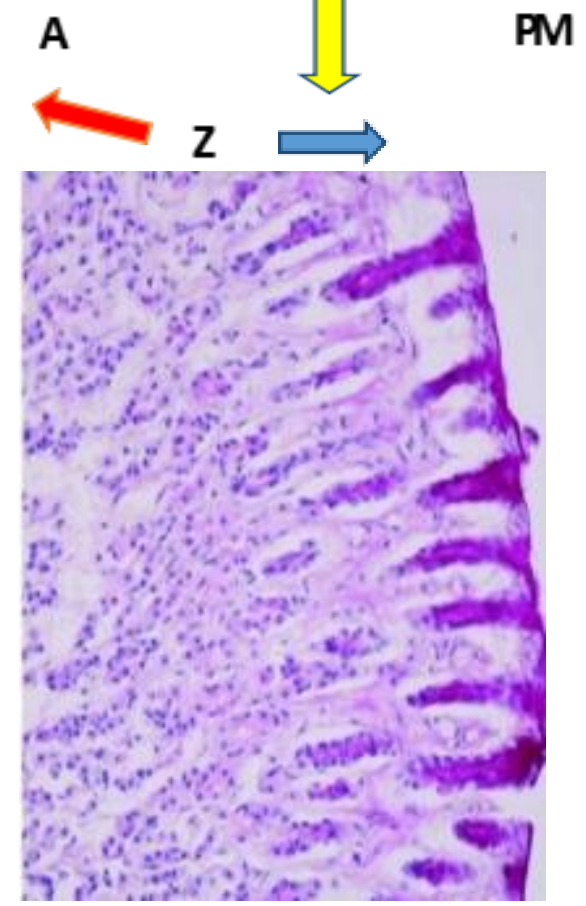 & 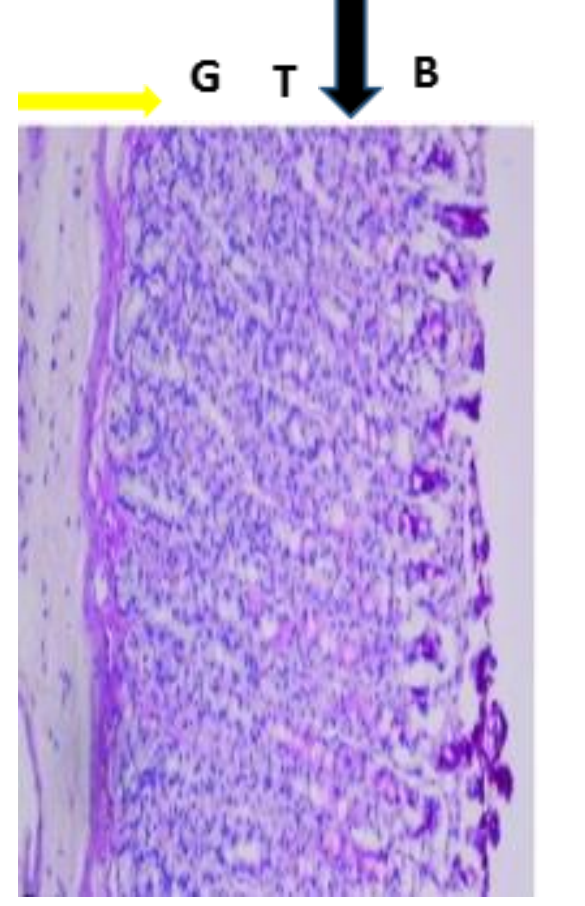 & 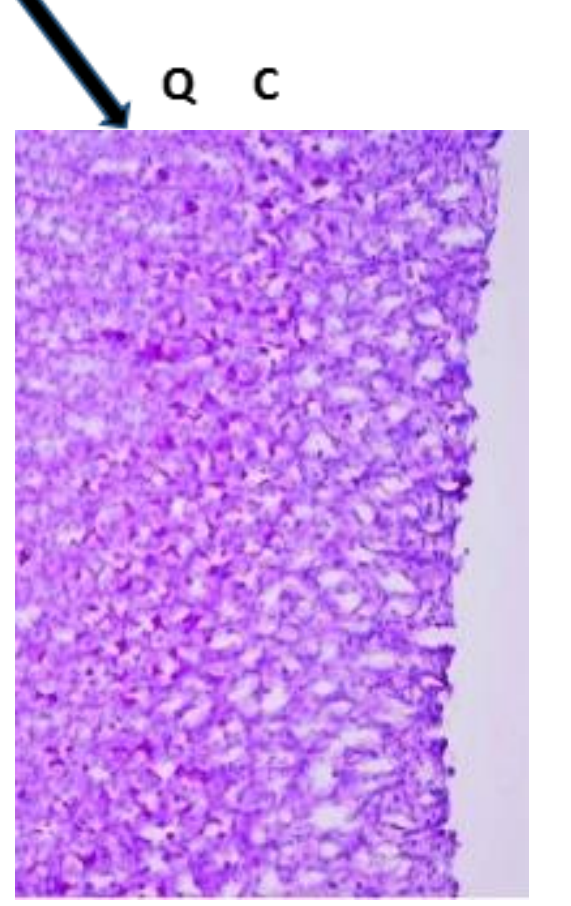 \\
\hline $\begin{array}{l}\text { Plate A (Negative control) Showed } \\
\text { several irregularity in gastric mucosa, } \\
\text { such as severe desquamation (Red arrow) } \\
\text { and loss of surface epithelial cell (blue } \\
\text { arrow), necrosis, vacuolization, edema } \\
\text { and dilated gastric glands along with } \\
\text { infiltration of inflammatory cells (yellow } \\
\text { arrow) }\end{array}$ & $\begin{array}{l}\text { Plate B (Positive control) revealed few } \\
\text { superficial surface of mucosa (black } \\
\text { arrow), gastric glands appeared normal } \\
\text { without inflammatory cells infiltration } \\
\text { (yellow arrow). Histoarchitecture not } \\
\text { affected }\end{array}$ & $\begin{array}{l}\text { Plate C Aqueous extract } \mathbf{2 5 0} \mathbf{m g} / \mathbf{k g} \text { ) } \\
\text { The mucosa was infiltrated by } \\
\text { inflammatory cells (Black arrows) that } \\
\text { almost displayed extensive edema }\end{array}$ \\
\hline 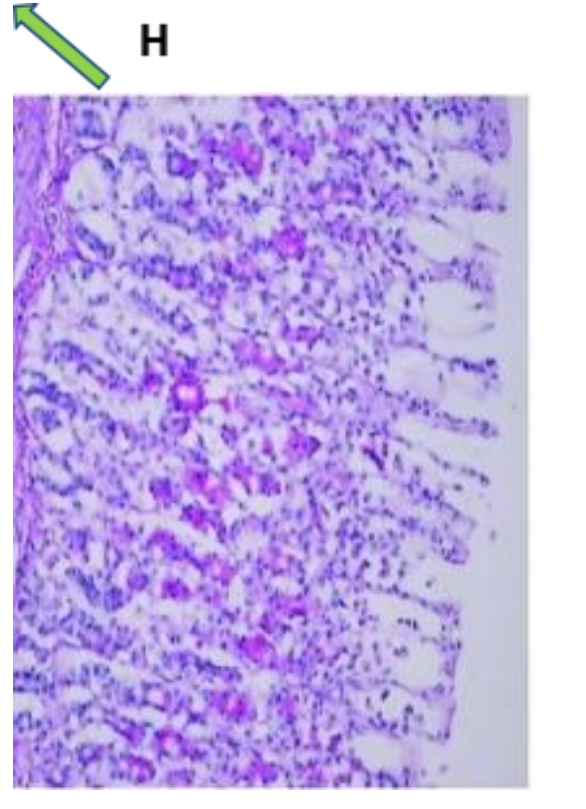 & 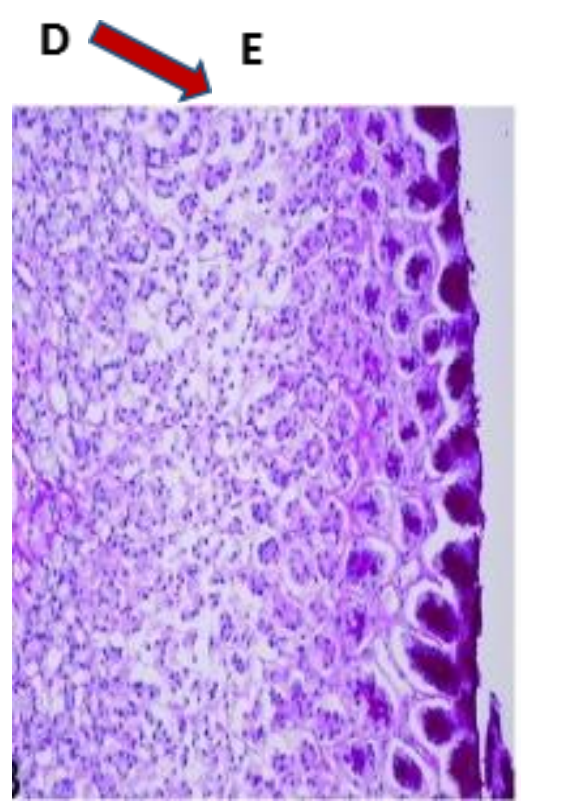 & 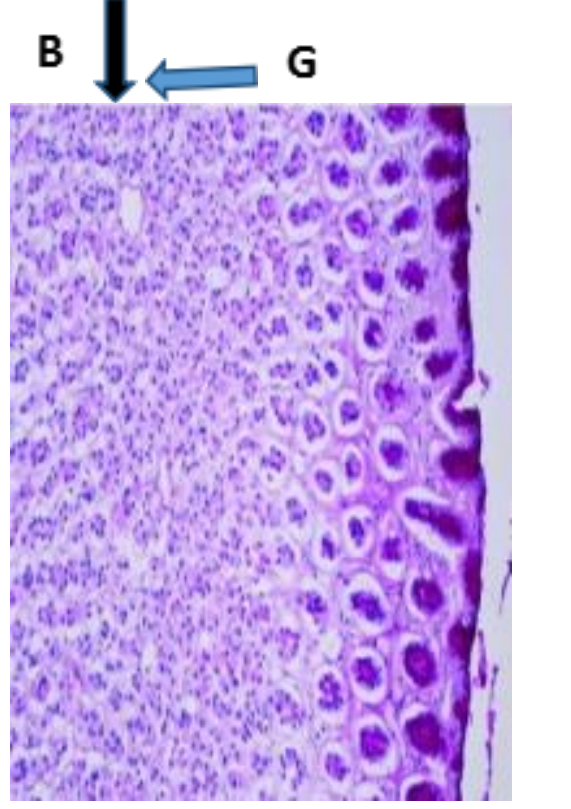 \\
\hline $\begin{array}{l}\text { Plate D (Aqueous extract } \mathbf{5 0 0} \mathbf{m g} / \mathbf{k g} \text { ) } \\
\text { Histological assessment of gastric mucosa } \\
\text { showed mild appearance of hemorrhage } \\
\text { (Green arrow). }\end{array}$ & 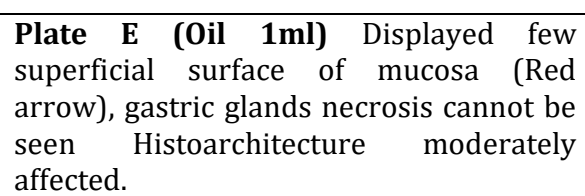 & $\begin{array}{l}\text { Plate F (1.5ml) Gastric mucosa exhibited } \\
\text { focal loss of superficial gastric epithelium } \\
\text { (blue arrow). The gastric glands were } \\
\text { almost normal in appearance(black } \\
\text { arrow) }\end{array}$ \\
\hline
\end{tabular}

Figure 6: Histology of the isolated stomach of experimental rats 


\section{Fourier transform infrared spectroscopy (FTIR)}

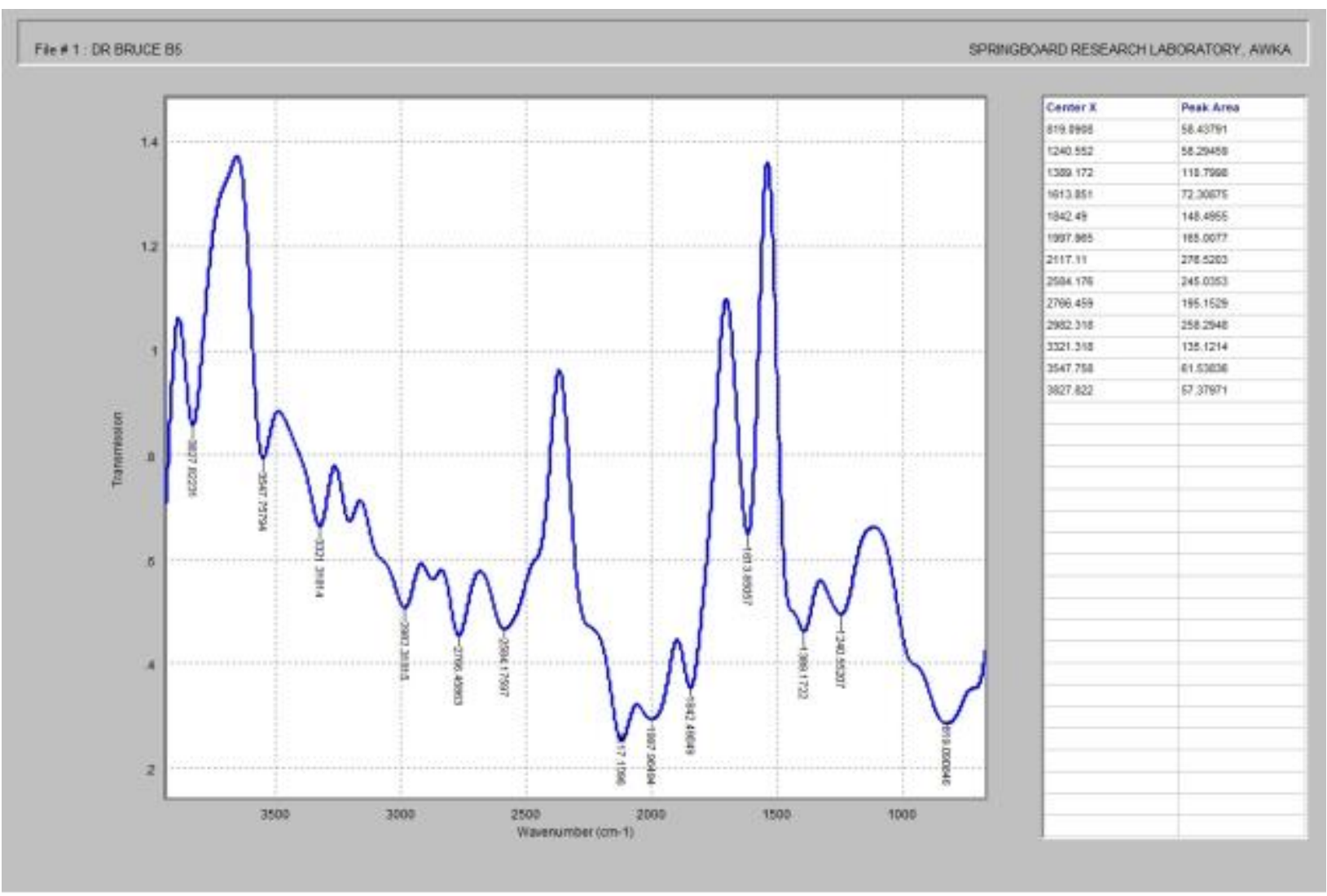

Figure 7: Fourier transform infrared spectroscopy (FTIR) of Nigella sativa seed extract

Table 7: Interpretation of FTIR Spectra of Nigella sativa seed extract

\begin{tabular}{|c|c|c|c|}
\hline $\mathbf{S} / \mathbf{N}$ & Frequency & Functional group & Compounds \\
\hline 2 & 1240.552 & R-0-R & Ether C0 symmetric stretch \\
\hline 3 & 1389.172 & $\mathrm{H}_{2} \mathrm{C}=\mathrm{CH}_{2}$ & Ethene $\mathrm{CH}$ symmetric stretch \\
\hline 4 & 1613.851 & $\mathrm{RNH}_{3}$ & $1^{0}$ amine $\mathrm{NH}$ stretch \\
\hline 6 & 1997.965 & $\mathrm{R}-\mathrm{S}-\mathrm{C} \equiv \mathrm{N}$ & Thiocyanate SCN antisymmetric stretch \\
\hline 7 & 2117.110 & $\mathrm{RCOOH}$ & Carboxylic acid C0 stretch \\
\hline 8 & 2584.176 & $\mathrm{R}-\mathrm{C} \equiv \mathrm{N}$ & Nitriles CN antisymmetric stretch \\
\hline 9 & 2766.459 & $\mathrm{CH}_{2}$ & Methylene CH stretch \\
\hline 12 & 3547.758 & $\mathrm{R}_{3} \mathrm{CHOH}$ & $3^{0}$ alcohol $0 \mathrm{H}$ stretch \\
\hline 13 & 3827.822 & $\mathrm{R}_{3} \mathrm{CHOH}$ & $3^{0}$ alcohol $0 \mathrm{H}$ stretch \\
\hline
\end{tabular}




\section{Gas Chromatography Mass Spectroscopy (GC-MS)}

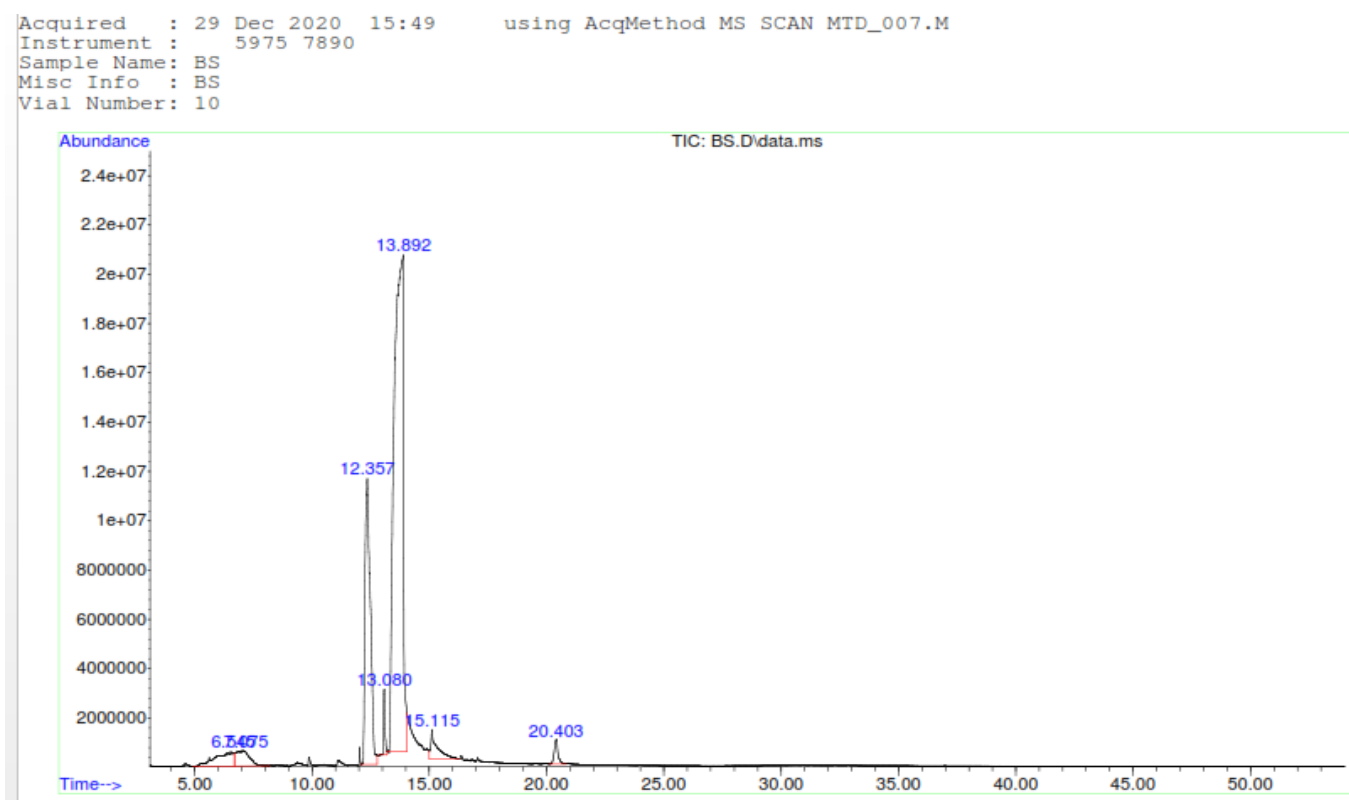

Figure 8: Gas Chromatography Mass Spectroscopy (GC-MS) chromatogram of Nigella sativa seed extract

Table 8: Interpretation of Gas Chromatography Mass Spectroscopy (GC-MS) of Nigella sativa seed extract

\begin{tabular}{|c|c|c|c|c|c|}
\hline PEAK & $\begin{array}{l}\text { RETENTION } \\
\text { TIME (RT) }\end{array}$ & AREA & $\begin{array}{l}\text { LIBRARY } \\
\text { (NIST) }\end{array}$ & FORMULAR & BIOLOGICAL ACTIVITIES \\
\hline 1 & 6.545 & 3.71 & Glycerin & $\mathrm{C}_{3} \mathrm{H}_{8} \mathrm{O}_{3}$ & Laxative, Antibacterial27. \\
\hline 2 & 7.075 & 2.99 & Glycerin & $\mathrm{C}_{3} \mathrm{H}_{8} \mathrm{O}_{3}$ & Laxative, Antibacterial27. \\
\hline 3 & 12.357 & 21.76 & $\begin{array}{l}\text { n-Hexadecanoic } \\
\text { acid }\end{array}$ & $\mathrm{C}_{16} \mathrm{H}_{32} \mathrm{O}_{2}$ & $\begin{array}{l}\text { Antioxidant, Antiulcer, } \\
\text { Antiandrogenic, flavour, Pesticide, 5- } \\
\text { Alpha reductase inhibitor, } \\
\text { Hypocholesterolemic, Hemolytic, } \\
\text { Nematicide, Lubricant } 27,28 \text {. }\end{array}$ \\
\hline 4 & 13.080 & 1.48 & $\begin{array}{l}\text { 9, 12- } \\
\text { Octadecadienoic } \\
\text { acid-methyl } \\
\text { ester }\end{array}$ & $\mathrm{C}_{19} \mathrm{H}_{34} \mathrm{O}_{2}$ & $\begin{array}{l}\text { Antiacne, antiulcer, 5-Alpha } \\
\text { reductase inhibitor, Antiandrogenic, } \\
\text { Antiarthritic, Anticoronary, } \\
\text { Insectifuge } 27,28 \text {. }\end{array}$ \\
\hline 5 & 13.892 & 66.06 & $\begin{array}{l}9, \quad 12- \\
\text { Octadecadienoic } \\
\text { acid }\end{array}$ & $\mathrm{C}_{18} \mathrm{H}_{32} \mathrm{O}_{2}{ }^{\circ}$ & $\begin{array}{l}\text { Antiacne, antiulcer, 5-Alpha } \\
\text { reductase inhibitor, Antiandrogenic, } \\
\text { Antiarthritic, Anticoronary, } \\
\text { Insectifuge } 27,28 \text {. }\end{array}$ \\
\hline 6 & 15.115 & 2.67 & $\begin{array}{l}9, \quad 12- \\
\text { Octadecadienoic } \\
\text { acid }\end{array}$ & $\mathrm{C}_{18} \mathrm{H}_{32} \mathrm{O}_{2}{ }_{\mathrm{OH}}^{\mathrm{O}}$ & $\begin{array}{l}\text { Antiacne, antiulcer, 5-Alpha } \\
\text { reductase inhibitor, Antiandrogenic, } \\
\text { Antiarthritic, Anticoronary, } \\
\text { Insectifuge } 27,28 \text {. }\end{array}$ \\
\hline 7 & $\begin{array}{l}20.403 \\
20.409\end{array}$ & 1.33 & $\begin{array}{l}\text { 9, } 12- \\
\text { Octadecadienoyl } \\
\text { chloride }\end{array}$ & $\mathrm{Cl}_{18}$ & $\begin{array}{l}\text { Antiacne, antiulcer, 5-Alpha } \\
\text { reductase inhibitor, Antiandrogenic, } \\
\text { Antiarthritic, Anticoronary, } \\
\text { Insectifuge } 27,28 \text {. }\end{array}$ \\
\hline
\end{tabular}




\section{DISCUSSION}

Gastric ulcer is due to an imbalance between protective and aggressive factors in the stomach, which is caused by the infection of Helicobacter pylori ${ }^{29}$, non-steroid antiinflammatory drugs, stress condition, and alcohol consumption ${ }^{30}$, 31. Microscopic and pharmacognostic standardization will help in the identification and authentication of the genuine plant materials, the presence of starch grains, Lignified tissues, cellulose, proteins, and oil globules, as shown in tables 1 and 2. A previous result of the macroscopic characteristics of $N$. sativa seed includes epidermal cells are irregular in shape, trichomes are nonglandular, and stomata are actinocytic with a broad base. Some previous studies also show similar results ${ }^{32}$. The leaf epidermal features which include types of stomata, epidermal cells, and hairs are significant tools in delimiting the taxonomy in many plants ${ }^{33}, 34,35,36$. Ahmad et al 37 reported variations in the pattern of the epidermal cells that can be used as an important microscopic tool to identify many closely related species. The study of trichomes has been found useful by many researchers 38,39 .

The proximate composition of Nigella sativa seed extract contains moisture content $5.3 \%$, total ash $4.8 \%$, acid insoluble ash $1.0 \%$, water-soluble ash $1.3 \%$, acid insoluble ash $1 \%$, water-soluble extractive value $8.5 \%$, and alcohol soluble extractive value $7.0 \%$ as shown in table 3 . In this study, the increased value of water-soluble extract indicates that Nigella sativa seed extract dissolves more in water than alcohol and also should extract more secondary metabolites. Fluorescence analysis is also required to evaluate the purity of plant crude ${ }^{40}$. The crude drug moisture content should not be greater than $14 \% \mathrm{w} / \mathrm{w}^{41}$. The growth of microorganism (yeast and fungi) is enhanced by high moisture content of crude drugs, causing the breakdown of crucial bioactive compounds. The high value of ash is due to contamination and the presence of impurities ${ }^{42}$. Pharmacognostic and physicochemical studies of the plant parts act as a reliable tool for detecting adulteration and plant identification ${ }^{43,44,45}$.

The phytochemical screening of Nigella sativa aqueous seed extract showed the presence of saponins, alkaloids, flavanoids, tannins, glycosides, carbohydrates, and reducing sugar. Saponins, flavonoids, alkaloids, fats and oils are present in huge amounts, as shown in table 4. Previous studies of the phytochemical screening of the $P$. nitida seed extract indicate the presence of alkaloids, saponins, flavonoids, cardiac glycoside, terpenoids, protein, and carbohydrates. Some of the phytochemical compounds detected such as glycoside, saponins, tannins, flavonoids, terpenoids, and alkaloids have been reported to have antimicrobial activity 42,46 . It is significant to note that alkaloids contribute to plant species fitness for survival. Some alkaloids and saponins have been found to possess antimicrobial activity 47 . Flavonoids have been shown to have antibacterial, anti-inflammatory, antiallergic, antiviral, antineoplastic, antiulcer activity ${ }^{48,49}$.

The result of the acute toxicity after 24 hours of administration of the various doses $(10,100$ and $1000 \mathrm{mg} / \mathrm{kg}$ body weight) of the aqueous extract of Nigella sativa in the first phase and the second phase, three-dose ranges were also used 2000, 3000, 4000 and $5000 \mathrm{mg} / \mathrm{kg}$ body weight and there was no death after 24 hours. Therefore, the $\mathrm{LD}_{50}$ was taken to be above $5000 \mathrm{mg} / \mathrm{kg}$ practically did not cause any death nor any sign of toxicity observed. Okoye et al ${ }^{50}$ carried out the $\mathrm{LD}_{50}$ of combined aqueous extracts of Ocimum gratissimum and Anacardium occidentale (1:1) at a dose of $5000 \mathrm{mg} / \mathrm{kg}$ orally which practically did not cause any death nor any sign of toxicity observed.

High concentrations of ethanol induce vascular endothelium injury of the gastric mucosa, which become edematous, and congestive, present point and scattered bleeding lesions, focal hemorrhage, necrosis, and giant deep ulcers were visible. The aqueous extract $(250 \mathrm{mg} / \mathrm{kg}$ and $500 \mathrm{mg} / \mathrm{kg}$ ) and oil extract (1 $\mathrm{ml}$ and $1.5 \mathrm{ml})$ showed a significant reduction $(\mathrm{p}<0.05)$ in ulcer index, total acidity, Gastric acid volume, and $\mathrm{pH}$ of gastric secretion, when compared with the negative control Distilled water $(1 \mathrm{ml} / \mathrm{kg})$ as shown in Table 6 . The effect of aqueous and oil extracts are dose-dependent. The rats pretreated with $N$. sativa aqueous extract $(500 \mathrm{mg} / \mathrm{kg}$ and $250 \mathrm{mg} / \mathrm{kg}$ ) and oil extract $(1.5 \mathrm{ml} / \mathrm{kg}$ and $1 \mathrm{ml} / \mathrm{kg})$ showed a significantly reduction in Ulcer index $(4.05 \pm 0.9,8.68 \pm 0.54$ and $4.62 \pm 0.19$, $8.87 \pm 0.4)$, than those of rats pretreated with the negative control Distilled water $(1 \mathrm{ml} / \mathrm{kg})(13.00 \pm 0.54)$ at $\mathrm{p}<0.05$. The maximum effect was observed at $500 \mathrm{mg} / \mathrm{kg}$ of the aqueous extract with ulcer index of $(4.05 \pm 0.9)$ and $1.5 \mathrm{ml}$ of the oil gave an ulcer index of (4.62 \pm 0.19$)$, as compared with the negative control Distilled water $(1 \mathrm{ml} / \mathrm{kg})$ with ulcer index of $13.00 \pm 0.54$ is an indication that the extract can protect the stomach lining from ethanol-induced mucosal damage.

The rats pretreated with $N$. sativa aqueous extract $(500 \mathrm{mg} / \mathrm{kg}$ and $250 \mathrm{mg} / \mathrm{kg}$ ) and oil extract $(1.5 \mathrm{ml} / \mathrm{kg}$ and $1 \mathrm{ml} / \mathrm{kg}$ ) showed a significantly reduction in total acidity $(55.6 \pm 0.13$, $89.09 \pm 0.74$ and $67.1 \pm 0.31,80.97 \pm 0.33$ ), than those of rats pretreated with the negative control Distilled water $(1 \mathrm{ml} / \mathrm{kg})$ $(120.4 \pm 0.40)$ at $p<0.05$. The maximum effect was observed at $500 \mathrm{mg} / \mathrm{kg}$ of the aqueous extract with total acidity of $(55.6$ $\pm 0.13)$ and $1.5 \mathrm{ml}$ of the oil gave total acidity of $(67.1 \pm 0.31)$, as compared with negative control Distilled water $(1 \mathrm{ml} / \mathrm{kg})$ with a total acidity $(120.4 \pm 0.40)$. The rats pretreated with $N$. sativa aqueous extract $(500 \mathrm{mg} / \mathrm{kg}$ and $250 \mathrm{mg} / \mathrm{kg})$ and oil extract $(1.5 \mathrm{ml} / \mathrm{kg}$ and $1 \mathrm{ml} / \mathrm{kg})$ showed a significantly reduction in Gastric acid volume $(4.45 \pm 0.5,6.07 \pm 0.51$ and $5.00 \pm 0.71,6.20$ \pm 0.45 ), than those of rats pretreated with the negative control Distilled water $(1 \mathrm{ml} / \mathrm{kg})(7.20 \pm 0.09)$ at $\mathrm{p}<0.05$. The maximum effect was observed at $500 \mathrm{mg} / \mathrm{kg}$ of the aqueous extract with the Gastric acid volume $(4.45 \pm 0.5)$ and $1.5 \mathrm{ml}$ of the oil with the gastric acid volume $(5.00 \pm 0.71)$, as compared with the negative control Distilled water $(1 \mathrm{ml} / \mathrm{kg})$ with the acid volume (4.18 \pm 0.31$)$. Finally, the rats pretreated with $N$. sativa aqueous extract $(500 \mathrm{mg} / \mathrm{kg}$ and $250 \mathrm{mg} / \mathrm{kg}$ ) and oil extract $(1.5 \mathrm{ml} / \mathrm{kg}$ and $1 \mathrm{ml} / \mathrm{kg})$ showed a significantly reduction in the $\mathrm{pH}$ of gastric secretion $(3.67 \pm 1.76,4.7 \pm 1.0$ and $3.54 \pm 2.00,3.74 \pm 1.86$ ), than those of rats pretreated with the negative control Distilled water $(1 \mathrm{ml} / \mathrm{kg})(2.20 \pm 0.10)$ at $\mathrm{p}<0.05$. The $\mathrm{pH}$ of gastric secretion of $500 \mathrm{mg} / \mathrm{kg}$ of the aqueous extract $(3.67 \pm 1.76)$ and $1.5 \mathrm{ml}$ of the oil $(3.54 \pm 2.00)$ has the maximum effect, as compared with the negative control Distilled water $(1 \mathrm{ml} / \mathrm{kg})(2.20 \pm 0.10)$.

Ethanol induces gastric mucosal damage by promoting disturbances of mucosal microcirculation, ischemia, endothelin release, degranulation of mast cells, inhibition of prostaglandins and decrease of gastric mucus production 51,52 . Ethanol rapidly penetrates the gastric mucosa causing injury characterized by membrane damage, erosive hemorrhagic lesions with diffuse coagulative cell necrosis, cell exfoliation, multiple superficial erosions, marked vascular congestion and ulcer formation $53,54,55$. 
Histological examination of the stomach of rats pretreated with negative control showed irregularity in gastric mucosa, such as severe desquamation (Red arrow) and loss of surface epithelial cell (blue arrow), necrosis, vacuolization, edema and dilated gastric glands along with infiltration of inflammatory cells (yellow arrow). The stomach of rats pretreated with the positive control (Famotide) revealed a few superficial surfaces of mucosa (black arrow), gastric glands appeared normal without inflammatory cells infiltration (yellow arrow). Histoarchitecture not affected. The stomach of rats pretreated with $N$. sativa aqueous extract $(250 \mathrm{mg} / \mathrm{kg})$ showed the mucosa was infiltrated by inflammatory cells (Black arrows) that almost displayed extensive edema. The stomach of rats pretreated with $N$. sativa aqueous extract $(500 \mathrm{mg} / \mathrm{kg})$ showed the mild appearance of hemorrhage (Green arrow). The stomach of rats pretreated with $N$. sativa oil extract $(1 \mathrm{ml})$ displayed few superficial surfaces of mucosa (Red arrow), gastric glands necrosis cannot be seen histoarchitecture moderately affected. The stomach of rats pretreated with $N$. sativa oil extract $(1.5 \mathrm{ml})$ showed that gastric mucosa exhibited focal loss of superficial gastric epithelium (blue arrow). The gastric glands were almost normal in appearance (black arrow). The healing process of gastric ulcer including several processes in gaster mucous e.g. congestive, hemorrhagic, edema, necrosis, inflammation, erosion, ulceration and dysplastic change ${ }^{56}$. Evaluation for the healing process in the clinical setting was based on visual endoscopy, but this study was based on microscopic evaluation and gastric ulcer determination. Microscopic evaluation showed gastric glands dilatation, increase of connective tissue, increase of micro vascularization, and recovery of a sensory nerve. It could be the basis for evaluating the quality of the healing process of gastric ulcers 57,58 .

Fourier Transformed Infrared (FTIR) technique is an important tool used to identify the characteristic functional groups, which are instrumental in the determination of functional groups and organic compounds inherent in any given sample. The peak value $819.0908 \mathrm{~cm}^{-1}$ was assigned to the C-CI stretching vibration of the halogeneous compound. The absorbance $1240.552 \mathrm{~cm}^{-1}$ was assigned to the C0 stretching vibration of the ether compound. The peak value $1389.172 \mathrm{~cm}^{-1}$ was assigned to the $\mathrm{C}=\mathrm{C}$ stretching vibration of the ethene compound. The medium band $1613.851 \mathrm{~cm}^{-1}$ corresponds to the $\mathrm{NH}$ stretching vibration of $1^{0}$ amine compound. The absorption $1842.490 \mathrm{~cm}^{-1}$ was assigned to the C0 stretching vibration of the cyclic ester compound. The peak value $1997.965 \mathrm{~cm}^{-1}$ and $2982.318 \mathrm{~cm}^{-1}$ were both assigned to the SCN stretching vibration of thiocyanate compound respectively. The band $2117.110 \mathrm{~cm}^{-1}$ was assigned to the $\mathrm{C00}$ anti-symmetric stretching vibration of carboxylic acid whereas the absorbance $2584.176 \mathrm{~cm}^{-1}$ was assigned to the $\mathrm{CN}$ anti-symmetric vibration of nitrile compound. The weak band $2766.459 \mathrm{~cm}^{-1}$ was assigned to the $\mathrm{C}-\mathrm{H}$ stretching vibration of methylene compound. The broadband $3321.318 \mathrm{~cm}^{-1}, 3547.758 \mathrm{~cm}^{-1}$ and $3827.822 \mathrm{~cm}^{-1}$ were assigned to $\mathrm{OH}$ stretching vibration of $1^{0} \& 3^{0}$ alcoholic compounds respectively, which revealed the highest peaks. Other functional groups such as chloro, ether, amine, carboxylic acid, nitriles, and methylene were equally present (table 7). The presence of various functional groups and phytocompounds in Nigella sativa confirm that it acts as the most important source of drugs against various ailments. Onyemailu et al ${ }^{59}$ carried out UV-Visible and FTIR Spectroscopic Analysis of the crude ethanolic extract of Peuraria phaseoloide Leaf (Roxb) Benth.
(Fabaceae) and the FTIR analysis revealed the highest peak at $3291.098 \mathrm{~cm}-1$, which signifies the presence of the R2NH 20 amine functional group. Other functional groups such as halogen, ether, ethane, carboxylic acid, carbonyl, nitrile, and alcohol were equally present.

GC-MS analysis is followed by library search of non-polar extract of the seed identified five compounds such as glycerin, n-Hexadecanoic acid, 9, 12-octadecadienoic acid-methyl ester, 9, 12-octadecadienoic acid and 9, 12-octadecadienoyl chloride. The compounds from the GC-MS investigation indicate the biological properties and in turn the pharmaceutical values of the study plant extract.

The GC-MS techniques have been proven to be suitable for the chemical profiling of medicinal plants ${ }^{60}$, these techniques provide a sufficient profile and identification of the compounds analyzed 61 .

Glycerin is known as glycerol, it is widely used in FDAapproved wound and burn treatments. It has been identified with retention times 6.545 and 7.075 , it has laxative and antibacterial properties 27 . Glycerol is a simple polyol compound. It is a colorless, odorless, viscous liquid that is sweet-tasting and non-toxic. The glycerol backbone is found in lipids known as glycerides. Glycerol has been detected in a good number of propolis samples from different regions around the world for example in Turkish propolis, Canadian propolis and Brazilian geopropolis $62,63,64$.

n-Hexadecanoic acid (palmitic acid) is a long-chain saturated fatty acid with a 16-carbon backbone commonly found in milk products, meat, and oil. It is the most common saturated fatty acid found in animals, plants and microorganisms. nHexadecanoic acid has been identified with a retention time of 12.357, it also has the following properties; nematicide, pesticide, lubricant, anti-androgenic, flavor, hemolytic 5-alpha reductase inhibitor, antioxidant and hypo-cholesterolemic features ${ }^{65}$

Among the identified phytochemicals, n-Hexadecanoic acid, 9, 12-octadecadienoic acid-methyl ester, 9, 12-octadecadienoic acid and 9, 12-octadecadienoyl chloride have the property of antioxidant, hypocholesterolemic, nematicide, pesticide, lubricant, antiacne, antiulcer, 5-Alpha reductase inhibitor, antiandrogenic, antiarthritic, and anticoronary activities ${ }^{66,67}$. $\mathrm{n}$-Hexadecanoic acid as the common compound in the leaves of $P$. stratiotes, Peuraria phaseoloides and E. crassipes.

9,12,15- Octadecatrienoic acid, methyl ester, (Z,Z,Z)- is a polyenoic fatty acid compound and it may act as an antiinflammatory, hypocholesterolemic, cancer preventive, hepatoprotective, nematicide, insectifuge, anti-histaminic, anti-arthritic, anticoronary, anti eczema, anti-acne, 5-alpha reductase inhibitor and anti-androgenic ${ }^{68,69}$.

\section{CONCLUSION}

The pharmacognostic properties can act as a reliable tool for the standardization and quality evaluation of the plant part. The anti-ulcerogenic properties exhibited by the plant extracts are due to the presence of secondary metabolites, this study suggests that aqueous and oil extract possesses antiulcer properties and thus the aqueous and oil extract of black seed can be considered as antiulcer medication traditionally. 


\section{ACKNOWLEDGMENTS}

The authors are thankful to Department of Pharmacognosy and Traditional Medicine, Nnamdi Azikiwe University, Awka, Nigeria, for access to scanning electron microscopy (SEM).

\section{CONFLICT OF INTEREST}

The authors have no conflict of interest.

\section{REFERENCES}

1. Singh B, Solanki RK, Status of seed spices research and development in India. Indian Journal of Agricultural Sciences, 2015; 85(2):1516.

2. Sharma NK, Ahirwar D, Jhade D, Gupta S, Medicinal and Phamacological Potential of Nigella sativa: A Review. Ethnobotanical Review, 2009; 13:946-55.

3. Oliveira AP, Santin JR, Lemos M, Klein-Junior LC, Couto AC, Meyre da Silva Bittencourt C, Cechinel-Eliho V, Faloni de Andrade S, Gastroprotective activity of methanol extract and marrubin obtained from leaves of Marrabinum vulgare L. (Lamiaceae). Journal of Pharmacy and Pharmacology, 2011; 63:1230-1237. https://doi.org/10.1111/j.2042-7158.2011.01321.x

4. Ramakrishnan K, Salinas RC, Peptic ulcer diseases. American Family Physician, 2007; 76:1005-1012.

5. Gupta S, Jhade D, Ahirwar D, and Sharma NK, Medicinal and pharmacological potentials of Nigella sativa. Ethnobotanical Review, 2009; 13:946-55.

6. Bruce SO, Onyemailu VO, Orji CE, Evaluation of the antiulcer activity and GC-MS spectroscopic Analysis of the crude ethanolic extract of Peuraria Phaseoloide Leaf (Roxb) Benth. (FABACEAE). World Journal of Pharmaceutical Research, 2021; 10(7):39-59.

7. Tsukimi H, Nakai S, Itoh K, Amagase S, Okabe S, Involvement of heat shock proteins in the healing of acetic acid-induced gastric ulcers in rats. Journal of Physiology and Pharmacology, 2001; 52:391405 .

8. Konturek PC, Konturek T, Brzozowski JW, Konturek JW, Pawlik WW, From nerves and hormones to bacteria in the stomach; Nobel prize for achievements in gastrology during last century. Journal of Physiology and Pharmacology, 2005; 52:507-530.

9. Kommu S, Gowrishankar NL, Shankar M, Suvetha K, Eswaraiah MC, Evaluation of anti-ulcer activity of methanolic extract of Balanites aegyptiaca L. Bark. International Journal of Phytopharmacology, 2013; 4:308-10.

10. Saha L, Bhatia A, Chakrabarti A, Gastroprotective effect of bezafibrate, a peroxisome proliferator activated receptor $\alpha$ agonist and its mechanism in a rat model of aspirin-induced gastric ulcer. Advances Digestive Medicine, 2016; 3:101-10. https://doi.org/10.1016/j.aidm.2016.04.001

11. Ezekwesili CN, Ghasi S, Adindu CS, Mefor NC, Evaluation of the antiulcer properties of aqueous extract of unripe Musa paradisiaca Linn. Peel in wistar rats. African Journal of Pharmacy and Pharmacology, 2014; 8(39):1006-1011.

12. Ingle KP, Deshmukh AG, Padole DA, Dudhare MS, Moharil MP, Khelurkar VC, Phytochemicals: Extraction methods, identification, and detection of bioactive compounds from plant extracts. Journal of Pharmacognosy and Phytochemistry, 2017; 6:32-6.

13. Milojevic JSZ, Stojanovic TD, Palic R, Lazic ML, Veljkovic VB, Kinetics of distillation of essential oil from comminuted ripe juniper (Juniperus communis L.) berries. Biochemical Engineering Journal, 2008; 39:547-553. https://doi.org/10.1016/j.bej.2007.10.017

14. Khandelwal KR, Practical Pharmacognosy. Pragati Books Pvt. Ltd. 2008; PP 220
15. Evans WC, Trease and Evans Pharmacognosy. WB Saunders Ltd. London, 2002; 32, 33, 95 - 99, 512, 547.

16. Eleazu C, Eleazu K, Determination of the proximate composition, total carotenoid, reducing sugars and residual cyanide levels of flours of 6 new yellow and white cassava (Manihot esculenta Crantz) varieties: American Journal of Food Technology, 2012; 7(10):642-649. https://doi.org/10.3923/ajft.2012.642.649

17. Onyegbule FA, Okoli OG, Bruce SO, "In vivo Evaluation of the Antimalarial Activity of the Aqueous Ethanol Extract of Monodora myristica Seed in Albino Mice", International Journal of Science and Research, 2019; 8(6):1530 - 1538.

18. Lorke DA, New approach to practical acute toxicity test. Archives of Toxicology, 1983; 54:279-86. https://doi.org/10.1007/BF01234480

19. Ihekwereme CP, Bruce SO, Orji CE, Ibe CI, Iloh E, Aqueous extracts of Ocimum gratissimum and Anacardium occidentale synergises in anti-diarrhoeal property. International Journal of Modern Pharmaceutical Research, 2020; 4(4):06-11.

20. Onyegbule FA, Bruce SO, Onyekwe ON, Onyealisi OL, Okoye PC, Evaluation of the in vivo antiplasmodial activity of ethanol leaf extract and fractions of Jatropha gossypifolia in Plasmodium berghei infected mice. Journal of Medicinal Plant Research, 2019; 13(11):269-279 https://doi.org/10.5897/JMPR2019.6766

21. Sabiu S, Garuba T, Sunmonu T, Ajani E, Sulyman A, Nurain I, Balogun A, Indomethacin-induced gastric ulceration in rats: Protective roles of Spondias mombin and Ficus exasperata. Toxicology Reports, 2015; 2:261-7. https://doi.org/10.1016/j.toxrep.2015.01.002

22. Mshelia HS, Karumi Y, Dibal NI, Therapeutic effect of Momordica balsamina leaf extract on ethanol-induced gastric ulcer in Wistar rats. Annals of Research Hospitals, 2017; 1:1-5. https://doi.org/10.21037/arh.2017.04.03

23. Boligon AA, de Freitas RB, de Brum TF, Waczuk EP, Klimaczewski CV, de Ávila DS, Athayde ML, de Freitas Bauermann L, Antiulcerogenic activity of Scutia buxifolia on gastric ulcers induced by ethanol in rats. Acta Pharmaceutical Sinica B, 2014; 4:358-67. https://doi.org/10.1016/j.apsb.2014.05.001

24. Farzaei MH, Khazaei M, Abbasabadei Z, Feyzmahdavi M, Mohseni GR, Protective effect of Tragopogon graminifolius DC against ethanol induced gastric ulcer. Iranian Red Crescent Medical Journal, 2013; 15:813-6. https://doi.org/10.5812/ircmj.7845

25. Van der Weerd J, Heeren, RMA, Boon JJ, Preparation methods and accessories for the infrared spectroscopic analysis of multi-layer paint. Studies in Conservation, 2004; 49:193-210. https://doi.org/10.1179/sic.2004.49.3.193

26. Onyemailu VO, Bruce SO, Iloh ES, UV-Visible and FTIR Spectroscopic Analysis of the Crude Ethanolic Extract of Peuraria Phaseoloide Leaf (Roxb) Benth. (FABACEAE). International Journal of Modern Pharmaceutical Research. 2021; 5(3):148-153.

27. Bruce SO, Onyemailu VO, Orji CE, Evaluation of the antiulcer activity and GC-MS spectroscopic analysis of the crude ethanolic extract of Peuraria Phaseoloide Leaf (Roxb) Benth. (FABACEAE). World Journal of Pharmaceutical Research, 2021; 10(7): 39-59.

28. Gnanavel V, Mary Saral A, GC-MS analysis of petroleum ether and ethanol leaf extracts from Abrus precatorius Linn. International Journal of Pharma and Bio Sciences, 2013; 4(3):37-44.

29. Chai J, Peptic Ulcer Disease. Rijeka, Croatia: InTech. 2011; ISBN: 978-953-307-976-9

30. Paguigan ND, Castillo DH, Chichioco-Hernandez CL, Anti-ulcer Activity of Leguminosae Plants. Argentina Gastroenterology, 2014; 51(1):64-7. https://doi.org/10.1590/S000428032014000100013 
31. Sultana S, Akram M, Asif HM, Akhtar N, Complementary and Alternative Approaches to Treat Peptic Ulcer. International Research Journal of Pharmacy, 2014; 5(5):353-59. https://doi.org/10.7897/2230-8407.050574

32. Yousaf Z, Shinwari ZK, Asghar R, Parveen A, Leaf epidermal anatomy of selected Allium species, family Alliaceae from Pakistan. Pakistan Journal of Botany, 2008; 40(1):77.

33. Naz N, Hameed M, Ashraf M, Ahmad R, Arshad M, Eco-morphic variation for salt tolerance in some grasses from Cholistan Desert, Pakistan. Pakistan Journal of Botany, 2009; 41(4):1707- 1714

34. Hameed M, Ashraf M, Naz N, Al-Qurainy F, Anatomical adaptations of Cynodon dactylon (L.) Pers. from the Salt Range Pakistan to salinity stress. I. Root and stem anatomy. Pakistan Journal of Botany, 2010; 42(1):279- 289.

35. Riaz A, Younis A, Hameed M, Kiran S, Morphological and biochemical responses of turf grasses to water deficit conditions. Pakistan Journal of Botany, 2010; 42(5):3441- 3448

36. Khan R, Abidin SZU, Mumtaz AS, Jamsheed S, Ullah H, Comparative leaf and pollen micromorphology on some Grasses taxa (Poaceae) distributed in Pakistan. International Journal of Nature and Life Sciences, 2017; 1(2):72- 82.

37. Ahmad K, Khan MA, Ahmad M, Shaheen N, Nazir A, Taxonomic diversity in epidermal cells of some sub-tropical plant species. International journal of Agricultural and Biology, 2010; 12(1):115- 118

38. Adedeji O, Leaf epidermal studies of the species of Emilia Cass. (Senecioneae, Asteraceae) in Nigeria. Botanica Lithuanica, 2004; 10(2):121- 133

39. Adedeji O, Ajuwon OY, Babawale 00, Foliar epidermal studies, organographic distribution and taxonomic importance of trichomes in the family Solanaceae. International Journal of Botany, 2007; 3(3):276- 282. https://doi.org/10.3923/ijb.2007.276.282

40. Kadam MPV, Yadav KN, Patel AN, Navsare VS, Bhilwade SK, Patil MJ, Phytopharmacopoeial specifications of Garcinia indica fruit rinds. Pharmacognosy Journal, 2012; 4(31):23- 28. https://doi.org/10.5530/pj.2012.31.5

41. Ilanchezhian R, Roshy JC, Acharya RN, Harisha CR, Shukla VJ, Pharmacognostical and physicochemical analysis of bhallataka (Semecarpus anacardium Linn.)-fruit. Pharmacognosy Journal, 2011; 3(20):9- 16. https://doi.org/10.5530/pj.2011.20.3

42. Bruce SO, Onyegbule FA, Ezugwu CO, Pharmacognostic, physicochemical and phytochemical evaluation of the leaves of Fadogia cienkowskii Schweinf (Rubiaceae). Journal of Pharmacognosy and Phytotherapy, 2019; 11(3):52-60. https://doi.org/10.5897/JPP2019.0552

43. Desai D, Chanda S, Pharmacognostic study and physicochemical analysis of leaves of Terminalia arjuna. Pharmacognosy Journal, 2014; 6(6):15-19. https://doi.org/10.5530/pj.2014.6.4

44. Zhao Z, Liang Z, Guo P, Macroscopic identification of Chinese medicinal materials: traditional experiences and modern understanding. Journal of Ethnopharmacology, 2011; 131:556561. https://doi.org/10.1016/j.jep.2011.01.018

45. Raj RSN, Radhamany PM, Pharmacognostic and physicochemical analysis on the leaves of Brunfelsia americana L. Asian Pacific Journal of Tropical Biomedicine, 2012; 543-546. https://doi.org/10.1016/S2221-1691(12)60178-6

46. Onyegbule FA, Ezenwa CJ, Bruce SO, Umeokoli BO, Standardization, chemical composition and antipyretic evaluation of methanol leaf extract and fractions of Chrysophyllum albidum (Sapotaceae). Tropical Journal of Natural Product Research, 2020; 4(6):216-222. https://doi.org/10.26538/tjnpr/v4i6.1
47. Osborn AE, "Saponins in Cereals", WHO Traditional. Phytochemistry, 2003; 62:1-4. https://doi.org/10.1016/S00319422(02)00393-X

48. Bruce SO, Onyegbule FA, Biosynthesis of Natural Products, IntechOpen, 2021; DOI: 10.5772/intechopen.97660. https://www.intechopen.com/onlinefirst/biosynthesis-ofnatural-products https://doi.org/10.5772/intechopen.97660

49. Bruce SO, Onyegbule FA, Ihekwereme CP, Evaluation of hepatoprotective and antimicrobial activities of ethanol extracts and fractions of Picralima nitida seed and pod. Journal of Phytomedicine and Therapeutic, 2016; 1(2):1 - 21.

50. Okoye VO, Bruce SO, Onyegbule FA, Phytochemical screening and pharmacognostic properties of Peuraria phaseoloides leaves (roxb) benth. (fabaceae). International Journal of Public Health, Pharmacy and Pharmacology, 2020; 5(2):11-24.

51. Awaad AS, Reham ME, Gamal AS, Natural products in treatment of ulcerative colitis and peptic ulcer. J. Saudi Chem. Soc, 2013; 17:101-124. https://doi.org/10.1016/j.jscs.2012.03.002

52. Arawwawala M, Thabrew I, Handunnetti S, Arambewela L, Antiinflammatory activity of Trichosanthes cucumerina Linn in rats. Journal of Ethnopharmacology, 2010; 131:538-543. https://doi.org/10.1016/j.jep.2010.07.028

53. Gazzieri D, Trevisani M, Springer J, Harrison S, Cottrell GS, Andre E Nicoletti P, Gems D, Partridge L, Stress response and aging: "that which does not kill us makes us stronger". Cell Metabolism, 2008; 7:200-203. https://doi.org/10.1016/j.cmet.2008.01.001

54. Bae, D. K., Park, D., and Lee, S.H. Different antiulcer activities of pantoprazole in stress, alcohol and pylorus ligation-induced ulcer models. Lab. Animal Res, 2011; 27(1):47-52. https://doi.org/10.5625/lar.2011.27.1.47

55. Baena JM, Lopez C, Hidalgo A, Rame F, Jimenez S, Garcia M, Relationship between alcohol consumption and the success of Helicobacter pylori eradication therapy using Omeprazole, Clarithromycin and Amoxycillin for one week. European Journal of Gastroenterology and Hepatology, 2002; 14(3):291-296. https://doi.org/10.1097/00042737-200203000-00014

56. Janfaza S, Janfaza E, The study of pharmacologic and medicinal valuation of thymoquinone of oil of Nigella sativa in the treatment of diseases. Annals of Biological Research, 2012; 3(4):1953-7.

57. Tarnawski AS, Ahluwalia A, Molecular Mechanisms of Epithelial Regeneration and Neovascularization during Healing of Gastric and Esophageal Ulcers. Current Medicinal Chemistry, 2012; 19(1):16-27. https://doi.org/10.2174/092986712803414088

58. Syamsu Rijal, Upik Anderiani Miskad, Djumadi Achmad, Rina Masadah, Dasril Daud, Cahyono Kaelan, Halida Rahawarin, Swandari Paramita, Yadi Yasir, Evaluation of Anti-ulcerogenic Activity in Oil Extract of Jintan Hitam (Nigella sativa) Against Ethanol Induced Gastric Ulcer in Mice (Mus musculus). American Journal of Clinical and Experimental Medicine, 2016; 4(6):179184 https://doi.org/10.11648/j.ajcem.20160406.14

59. Onyemailu VO, Bruce SO, Iloh ES, UV-Visible and FTIR Spectroscopic Analysis of The Crude Ethanolic Extract of Peuraria phaseoloide Leaf (Roxb) Benth. (FABACEAE). International Journal of Modern Pharmaceutical Research, 2021; 5(3):148-153.

60. Sforcin JM, Bankova JM, Propolis: Is there a potential for the development of new drugs? Journal of Ethnopharmacol, 2011; 133:253-260. https://doi.org/10.1016/j.jep.2010.10.032

61. Gomez-Caravaca AM, Gomez-Romero M, Arraez-Roman D, SeguraCarretero A, Fernandez-Gutierrez A, Advances in the analysis of phenolic compounds in products derived from bees. Journal of Pharmaceutical and Biomedical Analysis, 2006; 41:1220-1234. https://doi.org/10.1016/j.jpba.2006.03.002 
62. Kartal M, Kaya S, Kurucu S, GC-MS analysis of propolis samples from two different regions of Turkey. Zeitschrift Naturforschung C, 2002; 57:905-909. https://doi.org/10.1515/znc-2002-9-1025

63. Christov R, Trusheva B, Popova M, Bankova V, Bertrand M, Chemical composition of propolis from Canada, its antiradical activity and plant origin. Natural Product Research, 2006; 20:531536. https://doi.org/10.1080/14786410500056918

64. Araujo MJAM, Bufalo MC, Bruno JC, Fernandes Jr A, Trusheva B, Bankova V, Sforcin, JM, The chemical composition and pharmacological activities of geopropolis produced by Melipona fasciculata Smith in Northeast Brazil. Journal of Molecular Pathophysiology, 2015; 4:12-20. https://doi.org/10.5455/jmp.20150204115607

65. Komansilan A, Abadi AL, Yanuwiadi B, Kaligis DA, Isolation and Identification of Biolarvicide from Soursop (Annona muricata Linn) Seeds to Mosquito (Aedes aegypti) Larvae. International
Journal of Engineering \& Technology IJET-IJENS, 2012; 12(03): 28-32.

66. Jegadeeswari P, Nishanthini A, Muthukumaraswamy S, Mohan VR, GC-MS analysis of bioactive components of Aristolochia krysagathra (Aristolochiaceae). Journal of Current Chemical and Pharmaceutical Sciences, 2012; 2:226-236.

67. Upgade A, Anusha B, Characterization and medicinal importance of phytoconstiuents of Carica papaya from down south Indian region using gas chromatography and mass spectroscopy. Asian Journal of Pharmaceutical and Clinical Research, 2013; 6(4):101-106.

68. Wu L, Gao H, Wang X, Ye J, Lu J, Liang Y, Analysis of chemical composition of Chrysanthemum indicum flowers by GC/MS and HPTLC. Journal of Medicinal Plants Research, 2010; 4(5):421-426.

69. Vohra A, Kaur H, Chemical investigation of medicinal plant Ajuga bracteosa. Journal of Natural Product Plant Resources, 2011; 1(1):37-45. 